УДК 78.01/.03/.071.1+781.68/784.3

\author{
Ду Чжсоу \\ здобувач кафедры теорії музики і композиції \\ ОНМА ім. А. В. Нежданової \\ odma_n@ukr.net

\section{АВТОРСЬКА МОВА ЯК ЖАНРОВО-СТИЛЬОВИЙ ЧИННИК КАМЕРНО-ВОКАЛЬНОЇ ПОЕТИКИ Ф. ШУБЕРТА}

\begin{abstract}
Мета статті полягає у розробці теоретично поглибленого та оновленого підходу до аналізу камерно-вокальних ииклів Ф. Шуберта «Прекрасна мельничиха» та «Зимовий шлях». Методологія дослідження визначається авторологічним підходом, тобто націленістю на виявлення індивідуально-особистісних засобів створення музичної мови та формування цілісного образу автора, передбачає розвиток музично-семіологічного методу. Наукова новизна роботи полягає у виявленні особливоі «зустрічної драматургї», що виникає на основі виконавської інтерпретації та виражає взаємодію свідомості співака, як прямого «наратора», та композитора як єдиної авторської. Висновки дозволяють визначати основні рівні та способи втілення образу автора в шубертівських циклах, зокрема як індиціального знаково-формалізованого (абстрактного), взірцевого художнього, ідеального або третього у діалозі - над-адресата у смисловому вимірі художнього твору.
\end{abstract}

Ключові слова: авторська мова, образ автора, індиціальний автор, взірцевий автор, ідеальний автор, камерно-вокальна поетика Шуберта, цикл.

Du Zhou, applicant of the department of the Department of Music History and Musical Ethnography of the Odessa National A. V. Nezhdanova Academy of Music

Author's language as a genre-style factor of chamber-vocal poetry F. Schubert

The purpose of the article is to develop a theoretically in-depth and updated approach to the analysis of chamber vocal cycles $F$. Schubert's "Beautiful Melnichicha» and «Winter Road». The methodology of the research is determined by the authoritarian approach, that is, the tendency to identify individually personal means of creating a musical language and the formation of a holistic image of the author, involves the development of musical-semiological method. The scientific novelty of the work is to identify a special «counter-drama» that arises on the basis of performing interpretation and expresses the interaction of the singer's consciousness, as the direct «narrator», and the composer as the only author. The conclusions allow to determine the main levels and ways of realizing the author's image in Schubert's cycles, in particular as an individual sign-formalized (abstract), exemplary artistic, 
ideal or third in dialogue - Above-addressee in the semantic dimension of a work of art.

Keywords: author's language, author's image, individual author, exemplary author, ideal author, chamber vocal poetry of Schubert, cycle.

Ду Чжоу, соискатель кафедры теории музыки и композиции ОНМА им. А. В. Неждановой

Авторская речь как жанрово-стилевой фактор камерно-вокальной поэтики Шуберта

Цель статьи заключается в разработке теоретически углубленного и обновленного подхода к анализу камерно-вокальных ииклов Шуберта «Прекрасная мельничиха» и «Зимний путь». Методология исследования определяется авторологическим подходом, то есть нацеленностью на выявление индивидуально-личностных средств создания музыкального языка и формирования целостного образа автора, предполагает развитие музыкально-семиологического метода. Научная новизна работы заключается в выявлении особой «встречной драматургиш,, возникающие на основе исполнительской интерпретации и выражающей взаимодействие сознания певца, как прямого «нарратора», и композитора как единой авторской. Выводы позволяют определять основные уровни и способы воплощения образа автора в шубертовских циклах, в частности как индициального знаково-формализованного (абстрактного), образцового художественного, идеального или третьего в диалоге - над-адресата в смысловом измерении художественного произведения.

Ключевые слова: авторская речь, образ автора, индициальний автор, образиовый автор, идеальный автор, камерно-вокальная поэтика Шуберта, цикл.

Актуальність теми і проблеми статті. Коло літератури, присвяченої особистості та творчості Франца Шуберта, є надзвичайно великим та представляє різні хронологічні етапи розвитку наукової шубертіани, поєднує українських, російських та західноєвропейських дослідників, як історичного, так і теоретичного напряму [1-13].

Але все одно залишаються невирішені питання про стильове мислення та жанрові переваги, естетичні відкриття та художньо-мовні, зокрема музично-семантичні новації Шуберта, нарешті, все ще недостатньо чітко формулюється відповідь на питання, чому саме камерно-вокальна творчість композитора є найбільш помітною і відомою серед усього ним створеного.

Образний світ пісенної творчості Ф. Шуберта можна визначати як індивідуальне тлумачення універсальних начал та вимірів людського буття. Особливого значення тут набувають цикли «Прекрасна мельничиха» та «Зимовий шлях», що разом пропонують особливу сюжет- 
ну колізію та виступають цілісною художньою організацією, котра нагадує розгорнуту поемну форму.

Дані цикли утворюють разом безпрецедентний у мистецтві доби романтизму диптих, з яким можна порівняти лише деякі частини «Людської комедії» О. де Бальзака або, створені ще пізніше, вже у наступний стильовий період еволюції європейської літератури, твори Р. Роллана, але твори Шуберта перевершують названі зразки трагічним характером. Окрім цього, в даних двох циклах розвивається особливий вид музично-поетичного наративу, тобто якість оповідальності, причому як з ліричною поглибленістю, так і з певною філософсько-споглядальною відстороненістю від подій, про які розповідається. Погляд з середини дивним чином поєднується з поглядом згори та ззовні, і це досягається в основному музичними засобами, наприклад, головний настрій кожної частини зумовлюється загальним метроритмом, а стан персонажа-героя, інтенсивність його почуттів, активна зібраність або розгубленість, позитивна або негативна психологічна налаштованість передаються за допомогою фактурно-просторових рішень, наприклад, ущільнення, заповнення або розрідження пауз.

Останні набувають значення самостійного психологічного знаку, аж до назви окремого номера циклу, що свідчить про бажання героя зупинитися, відійти убік, відпочити або зовсім позбавитися попередніх обставин. Отже у характеристиці психологічного змісту, особистісних властивостей образу провідними стають музичні час та простір, причому у їх буквальному, можна сказати індиціальному вираженні.

У зв'язку з цим і не здаються перебільшенням слова про перевтілення автора в музику або про міфологізацію його образу безпосереднім художньо-знаковим шляхом. Можна сказати, що автор - ліричний герой твору - народжується і зникає разом з музичним текстом та тими семіологічними прийомами, які він у собі містить.

Методологія дослідження визначається авторологічним підходом, тобто націленістю на виявлення індивідуально-особистісних засобів створення музичної мови та формування цілісного образу автора, передбачає розвиток музично-семіологічного методу.

Основний зміст роботи. Провідні знаки-індекси як формалізовані мовні музичні прийоми, стилістичні семантичні формули як залучення асоціативно-змістового аспекту музичного діяння та логіки розгортання музичного тексу (з метою конкретизації), єдність усіх прийомів викладу за рахунок повторення та контрасту, означення композиційних меж, через які найбільш очевидною стає присутність 
вищої авторської волі, - таким є рівні втілення образу автора в циклах Ф. Шуберта.

Так, наприклад, в циклі «Прекрасна мельничиха» в першому номері, «В дорогу», перший рівень реалізується за рахунок активного руху з повторення метро-ритмічних фігур, що уподібнені загальним формулам інструментального викладу навіть в вокальній партії, переважаючого висхідного малюнку мотивів, дводольності, достатньо швидкого темпу, чіткого фразування з наголосом сильних долей, ритмічного подрібнення шістнадцятими в обох партіях, вокальній та фортепіанній. Другий побудований на алюзіях до пісні-маршу з прелюдійним оздобленням, ще й з гімнічними висхідними інтонаціями (чому сприяють і постійні глибокі октавні кроки в басу у фортепіано). Ідеальний автор постає у загальному образному напрямі цієї частини циклу як оптимістичного прологу усієї майбутньої музичної біографії автора - героя - персонажа Мельника, поета Мюллера (мельник німецькою), взагалі людини, сучасної до композитора та до романтичної кризи свідомості. Головна ідея упредметнюється в словесно зазначеному образі руху як притаманному найбільше воді, отже образи води і руху зливаються з ідеєю життя.

Звертаючись до розгляду змісту циклу «Зимовий шлях», вкажемо, що, по-перше, керуємося потребою виявлення головних сторін втілення образу автора як індиціального, взірцевого та ідеального, тобто прослідковуємо знаково-індексальний, стилістичний семантичнориторизований та образно-узагальнюючий рівні виразовості у кожному з номерів циклу, по-друге, вивчаємо побудову тексту цілісного твору з точки зору його звучної виконавської форми, тобто в актуалізованому дієвому аспекті; по-третє, в якості взірцевого ідеального використовуємо як аналітичну базу виконання Д. Фішера-Діскау у дуеті з Дж. Муром (запис 1962 р.).

Так, перший номер циклу, «Спокійно спи», відразу розпочинається з фатального остинатного ритму, акордової витриманості фактурного викладу зі специфічним відривчастим скерцозним штрихом та 3 низхідної спадаючої вокальної фрази, що йде нижче октавного ходу, чіпляє інтервал нони, утворюється між третім та другим ступенями ладу, ре мінору, якщо їх «перевернути» та розсунути у звуковому просторі. Водночас в ньому виникають м'які оспівування опорних тонів та повтори вокальних фраз на різних рівнях, чергування інтервально розширених та плавно-поступеневих вокальних інтонем, пожвавлююча активизуюча функція подріблення шістнадцятими тривалостя- 
ми, активні інтонаційні ходи по звуках тонічного тризвуку; також використовуються окремі унісоні повтори, котрі надають вольового відтінку висловленню. Зауважимо, що спосіб організації акордової фортепіанної фактури виступає передвісником шуманівського «Я не серджусь».

Другий номер, «Флюгер», вводить складно-унісонні пасажі в фортепіанній партії та підвищення рівня динаміки як у гучнісному, так і в темпоральному викладах, чергування лінеарного та акордово зібраного фактурного складу у фортепіано, відзначений особливим лаконізмом. Втім підсилення лаконізму музичного викладу, аж до афористичності, стає відмінною рисою даного, другого, циклу композитора.

Третій номер, «Застиглі сльози», вносить ще більший аскетизм музичного наративу, що підкреслюється тихою динамікою та стаккатним штрихом. Виявляються оповідальні інтонації, мовленнєві наголоси в вокальній партії, зображальні ефекти в фортепіанній, що супроводжуються змінами фактури; очевидним є посилення наскрізного розвитку матеріалу, контрасти всередині інтонування, як змішання декламаційної напористості та мелізматичних оздоблень.

Четвертий номер, «Заціпеніння», відзначений духом парадоксальності, що проявляється у поєднанні стрімкого темпу та характеру викладу з ідеєю заціпеніння; особливого значення набуває тріольна фігура - знак схвильованості та зростання нервової напруженості; мелодійний секвенційний розвиток у середній частині вносить бажаний контраст, часткове заспокоєння, хоча його порушують схвильовані запитальні ходи, ще одна версія тризвучної побудови, якою Шуберт володіє з майстерністю фокусника, виймаючи з однієї й тої самої структури тризвуку різні за семантичним навантаженням та емоційним знаком мотивні утворення. Можна зазначити повернення і навіть певне домінування фігуративно-прелюдійної сфери, що продовжується і у наступному номері.

Це «Липа», п’ятий номер, у якому виникає поетична вербалізована тема струмка, а в музичному плані звучить варіант мотиву першої частини, хоча в більш спокійному епічно-розповідному викладі. Утворюється тісна взаємодія вокального та фортепіанного тематизму, що передбачає алюзію до унісонного викладу другої частини.

Взагалі у другому циклі виникає особлива спорідненість усіх частин, наприклад, за рахунок розширення, драматичного ускладнення змісту деяких з них, у тому числі «Липи», а також підсилення моно- 
стилістичних зв'язків, моноінтонаційного розвитку; отже підсилення контрастності та цілісності відбувається одночасно. У «Липі» це веде до різноманіття видів фортепіанного фактурного викладу, до надання цьому номеру вигляду пісні-сценки.

Шостий номер, «Водний потік», виявляє ще одну особливість музичної мови циклу - особливе призначення квінто-квартових кроків, інтонаційних побудов, так би мовити порожніх, незаповнених мотивних зворотів, що підкреслюють спробу героя вийти за межі власних переживань, чергуються з гармонійними напружено-альтерованими ходами, $є$ інтенціонально значущими; до таких психологічних знаків додаються ритмічні пунктири, відтворюючи ритм серцебиття, відхід звучання до тихої динаміки та зупинки.

Сьомий номер, «У струмка», демонструє домінування втаємниченого стаккатного штриха - як частини образу струмка, що замерз, покрився кригою, втратив рухливість; дозволяє зрозуміти, що скерцозно-токкатна стилістика є провідником негативних оцінок. Тут дуже лаконічна, водночас виразна фортепіанна відривчаста фактура контрастує з кантиленними фразами вокаліста, але і останні вибудовуються як розрізнені репліки, тобто відокремлені, поєднуються в один тематичний потік лише у кульмінації, у якій набувають патетичного характеру, стають більш розспівними. Взагалі в цій частині, і за сюжетним словесним розгортанням, і за особливостями музичного розвитку, можна знайти риси баладності, особливо наприкінці фортепіанного викладу, останній «жест» якого - арпеджована побудова акорду.

Восьмий номер, «Спогад», знову нагадує про парадоксальні риси загального образу та характеру нарративу, коли відразу виникає гарячкова поспішність, що, втім, в середині змінюється дійсно спогадом з ліричними інтонаціями. Але у цілому відчуваються як домінантні і моторне начало, і галопуюча ритміка, хоча й облагороджена ліричним почуттям; цей номер сприймається як певна інтермедія, що покликана підкреслювати трагічний настрій та доленосні прийоми наступного.

Дев'ятий номер, «Блукаючий вогник», підкреслює особистіснотрагічні інтенції тридольної ритміки, особливо поєднаної з викладом $3 / 8$ та пафосними декламаційними ритмічними пунктирами у вокальній партії. Знову йдеться про струмки, які всі зіллються у морі, тобто водна стихія розширюється; але особливо фатально звучить остинатний мотив у фортепіанній партії на завершення номера, що свідчить про неспокій, душевні передвісники трагічної розв'язки. 
У десятому номері, «Відпочинок», поетично розповідається про втому всупереч назві; музичні октавні перегуки та речитативність 3 орнаментальними розспівними вставками виявляють, підсилюють це внутрішнє протиріччя. До нього спрямовані розділення вокальних реплік у часопросторі твору, нарощування діалогічності стосунків між фортепіанною та вокальною партіями, буквальні перегуки фраз між ними, що мовби прислухаються одна до одної, акордова впевненість, силова природа фортепіанного звучання та мелодійна витонченість вокального утворюють особливу динаміку образу.

Одинадцятий номер, «Весняний сон», є одним з найбільш світлих, у якому розвивається тема сну у його мрійно-утопічному вимірі, хоча даний вимір майже відразу порушується вторгненням іншого, поганого сну. Тут поєднані буквально говірні та узагальнено-танцювальні, але позбавлені прикладного змісту інтонаційні звороти; виникає особлива роль мелізмів та висхідних, полегшених стаккатним штрихом ходів у фортепіанній партії. Драматичні контрасти виражені перепадами гучнісної динаміки та змінами лінійно-пасажного й акордового викладу; дуже поміркованою виступає інтровертна інтонація, що знову узагальнюється баладним арпеджіато наприкінці фортепіанного викладу.

Дванадцятий номер, «Самотність», продовжує характер і тип побудови попереднього, включає декоративні тремоло в фортепіанній партії - явно ілюстративного призначення, також тріольні «фатальні» акордові напруження, що пов'язані з речитативними інтонаційними накопиченнями у вокальній партії. В образному аспекті жага бурі, образи бурі як насиченої подієвості у житті, протиставлені відчуттю жалюгідності людини, що не спроможна ані створити бурю, ані насолодитися спокоєм.

Тринадцятий номер, «Пошта», вводить ритм скачки - серцебиття, дозволяє розшифровувати логіку ритмічного пунктиру словами «як бурхливо серце у грудях стукає». У ньому до циклу знову входить тема сну - з питанням: навіщо сниться сон про любов? Звідси домінуючим стає питання про доцільність мрії, яке породжує активні висхідні інтонації.

Чотирнадцятий номер, «Сивини», знову пропонує широкі висхідні тризвукові інтонації, як знак душевної порожнечі, моральної спустошеності, водночас дуже мелодійно виразні про-оперні питання («невже я став старим»), як знак поглиблення трагічного стану та переживання страху. Відзначаються лаконізація фактури, паузи, уні- 
сонна оголеність вертикалі та декламаційна лапідарність горизонталі, вкраплення тріольних ритмічних фігур до вокальної партії у низхідному рисунку.

Наступний номер, «Ворон», відмічений, як важливим символом, початковим мотивом, що з'являється як у фортепіанній, так і у вокальній партії, багаторазово повторюється, тобто семантично закріплюється, містить виразну алюзію до секвенції Dies irae, тобто є символом смерті, виникає та розвивається на фоні тріольного руху шістнадцятими, але у сповільненому темпі, це дозволяє зазначати ще одну специфічну рису стилістики циклу: поєднання ліричних ритмічних одиниць $з$ помірним темпом, що дозволяє вбачати в них індекси високого психологічного напруження. Відхід у регістрові глибини в партії фортепіано поєднується з досить широким діапазоном вокальної партії.

Шістнадцятий номер, «Остання надія», відривчастою манерою викладу відразу наводить на думку про іронію, скепсис щодо надій людини на щастя, що підтверджується чергуванням діатонічних та хроматизованих інтонацій, введенням знову скерцозно-прелюдійного стилістичного плану музичної дії.

Сімнадцятий номер, «У селі», заснований на зображальній стилістиці, з настороженими роковими переборами в фортепіанній партії та урочисто-напруженим, водночас відсторонено споглядальним началом вокальної.

В середині йдеться про мрії та сни, тому відбуваються мажорне прояснення те регістровий підйом голосу. Це чергується між собою, внаслідок чого виникає такий собі самодіалог героя, що протестує проти власної свідомості та сприйняття: «тяжко бачити спокійно сплячих». Хоча мажорна музика на момент висловлення даної думки мовби суперечить значенню висловленого, до того ж завершення номера звучить досить спокійно.

Вісімнадцятий номер, «Непогожий ранок», знову постає картинною замальовкою, що виконана прямолінійно унісонно, є найбільш афористичною за формою та змістом частиною циклу.

Дев'ятнадцятий, «Обман», знову вводить майже шопенівську вальсовість у поєднанні з баркарольною ритмічною фігурою, надзвичайно щирі, лірично відверті інтонації, водночас полегшеність висловлення, що скоріше є світлим за почуттєвим станом, а це просвітлення і є оманливим, таким, що не відповідає дійсному перебігу подій. 
Двадцятий номер, «Подорожній стовп», це лірико-драматичний речитатив, що починається 3 провідних речитативних інтонацій, причому мелодія та фактура розвиваються уступами, досягаючи часткової кульмінації та втрачаючи внутрішню енергію, потім повертаючись до попереднього висотно-інтонаційного рівня. Таким чином засвідчується неможливість подолати інерцію буття; маршово-хоральна підоснова забезпечує «заціпенілість» інтонаційного контуру, а перемога речитації як способу вокально-інтонаційного викладу стан «остовпіння».

Двадцять перший номер, «Заїжджий двір», створює передчуття шопенівської баладності, надаючи ліричного переосмислення та мелодизації акордовому викладу у фортепіано. Секундово-терцієві звороти дозволяють дуже стисло та поступово розвивати вокальну мелодію, невідривно від словесної лінії, але з поступовим нарощуваннями активності та інтервального намагання відірватися від словесної поскладовості. Чергування мажорних та мінорних відблисків у музичному звучанні супроводжують домінуючий образ мандрівництва, що сам собою не є ані добрим, ані злим.

Двадцять другий номер, «Мужайся!» (нагадує за семантикою емоційною жестовістю назву «Моя!»), наповнений закличними інтонаціями, акумулює усі основні унісонно-акордові засоби, поєднуючи їх з гімнічними рисами, водночас з ритмічними пунктирами та поодинокими пасажно-орнаментальними прикрасами. Майже постійно присутній стаккатний скерцозний штрих стає своєрідним «словом від автора».

Двадцять третій, «Уявні сонця», один з найбільш складно символічних, що відбивається на стримано-поглибленому музичному змісті, хорально-маршового характеру, але з переважаннями вокального начала, декламаційній виразовості, у чергуванні реплік, водночас повній єдності партій, спрямованості до відтворення образу «блукання у ночі».

Двадцять четвертий, останній номер, «Шарманщик», знаменує остаточну зупинку - відсторонення, служить епілогом для обох циклів. Він відзначається підкресленою повторністю музичних формул, прозорістю фактури та діалогічною реплікоподібністю відносин фортепіанного та вокального викладів, елементами пентатонічності, взагалі домінуванням тризвучно-квартових інтервалів, тобто внутрішньо двокрокового заповнення октави, додаються і самі октавні кроки. У цілому у даному заключному «вірші з музикою» розвивається принцип мікроінтерваліки, який підтверджується і остинатно- 
унісонним мотивом, і запитальними інтонаціями, і поступеневими рухами, сприяє нарощуванню прихованої драматичної виразності. Знаменним $є$ завершення всього циклу «відкритим», тобто риторичним авторським, питанням: «Бажаєш, будемо разом під шарманку співати?». Питанням, зверненим до наступних поколінь композиторів, слухачів, виконавців...

Одним з таких виконавців, що прийняли естафету-виклик «з рук» Шуберта, був Дитрих Фішер-Діскау (1925-2012), який позиціонував себе як продовжувача традиції, яку він називав «культурою Lied» і вважав вже закритою галуззю - для композиторської творчості, але не для виконавської, навіть відзначав, що в останні десятиріччя (остання третина XX століття) вона почала цікавити молодих співаків більше, аніж раніше. Це свідчить про потребу у тій формі відтворення та трансляції почуттів, з якою пов'язані не лише жанр, а й епоха Lied, виражений в них образ людини.

Звучання голосу Д. Дішера-Діскау відрізняється унікальною тембральною та інтонаційною витриманістю, точністю, але найбільше образною виповненістю та природністю. Він однаково переконливо виконував ролі моцартівських, вердіївських, вагнерівських і штраусівських опер, брав участь у провідних оперних фестивалях, працював в Байройті, створив постмодерністський образ Вотана у манері «капіталістичного реалізму», але головним історичним внеском співака був розвиток саме виконавської культури Lied.

Співаку притаманне рідкісне вміння проникати до осередку авторського мислення, ставати врівень зі створюваними композитором героями, перевтілюватися у них, виражати звучним голосом, вимовлянням поетичного слова, артикуляційними та агогічними засобами головну смислову ідею - ідеальний рівень здійснення художньої концепції. Завдяки йому виконання камерних творів не лише стало пріоритетною творчою сферою провідних співаків, а й показником вищої виконавської майстерності.

Д. Фішер-Діскау підходив до виконання романтичної камерновокальної музики зі справжньою дослідницькою глибиною. Будучи автором 14 книг (в основному написаних в 1990-х роках), він половину з них присвятив вивченню творчості Шуберта, Шумана, поетів XIX століття, питанням співвідношення поетичного слова та музичного інтонування, історії німецької Lied, проблемі декламаційних чинників вокального вимовлення, ролі словесно-мовної основи у виконанні вокальних творів тощо. 
Входячи до світу музики Ф. Шуберта, Д. Фішер-Діскау повинен був відчути особливу близькість до його творчої особистості та почуттів створеного ним персонажа, адже сам пережив трагічну історію кохання, період відчаю та важкого повернення до життєвих та художніх інтересів.

Знаючи і глибоко розуміючи, чим є душевна рана, співак зумів донести це у тій інтерпретативній формі, яку передбачав у своїх циклах Ф. Шуберт, враховуючи ті її особливості, які пов'язані з багаторівневим та широким втіленням особистості самого композитора. Водночас йому вдалося відкрити і спорідненість особистостей поета і композитора, бездоганно доносячи інтонаційний зміст словесного тексту, дозволяючи слухачам розпізнавати усю його орфоепію як вже музичну піднесену та підсилену.

У виконанні Д. Фішером-Діскау циклу «Зимовий шлях» виявляється спорідненість принципів німецької та італійської вокальних шкіл, що повністю виправдано та доречно, враховуючи стилістичні складові твору, відображення в ньому деяких оперних, явно пов'язаних з італійським різновидом жанру, оперних прийомів. Співаку притаманні плавність, особлива континуальність звуковедення, відсутність будь-якого форсування, ясність та позбавлення зайвих призвуків словесної артикуляції, що дозволяє створювати справжню вокальну розповідь «від автора», природну, але смислово поглиблену.

Д. Фішер-Діскау веде свій інтонаційний камерно-вокальний наратив так, мовби сам $є$ його автором, створюючи враження «прямого мовлення», ніби співає душею, свідомістю самого Шуберта. Тому йому вдається розкрити усі ті тонкощі побудови музичного тексту, за якими прихований образ автора, відкрити та відтворити всі основні авторські музично-поетичні семантеми. Співак глибоко здійснює інтонаційну авторську нарацію, специфічні риси авторського вокального інтонування; за допомогою особливої динаміки вокального дихання досягає ідеального авторського рівня музично-інтонаційної емпатії.

Таким чином, наукова новизна роботи полягає у виявленні особливої «зустрічної драматургії», що виникає на основі виконавської інтерпретації та виражає взаємодію свідомості співака, як прямого «наратора», та композитора як єдиної авторської.

Висновки. Проведений аналіз дозволяє визначати в тексті циклів Ф. Шуберта декілька іпостасей образу автора, або декілька основних способів втілення авторського начала. 
Перший і основний з них полягає у створенні «прямої мови» авторської свідомості - сукупності музичних прийомів (засобів музичного викладу), які виражають відношення, у тому числі буквальне особистісне ставлення, до явищ, подій, стосунків, колізій буття, що відображені у творі, тобто є мовою авторської свідомості у ії найбільш глибинному вимірі. Але за законами музичної форми вони є іiі знаковою поверхнею, індексацією змісту, що дозволяє засвідчувати, фіксувати певні ознаки психологічних процесів. Індиціальний автор, таким чином, завжди є начальним та формальним у прямому значенні цього слова, він створює форму висловлення, до якої ще треба докласти змістові орієнтири - путівники. Індиціальний автор в музиці є синонімічним до абстрактного (нагадаємо матеріал першого підрозділу нашого дослідження), адже він дотичний не лише до всього, що відбувається у творі, а й до методів організації даного виду творчості, музики як художньо-смислового явища. Сформовані ним дороговкази є стилістичними нахилами, внутрішніми жанрово-семантичними формулюваннями, риторичними прийомами, які здатні формувати необхідні образно-асоціативні зв'язки, розширювати або звужувати сприйняття і розуміння музичного звучання.

За посередництвом жанрово-стилістичного упредметнення матеріалу до циклів входить автор взірцевий або автор як герой власної розповіді, тобто як взірець людської долі (вчинкової реальності), до якої причетна і авторська, але вже не до повного злиття, а за принципом комплементації або контамінації, з вивільненням змістових зон, що можуть належати комусь одному, або автору, або персонажу, залежно від точки зору. 3 даним рівнем авторизації твору пов'язані, насамперед, його музично-тематичні формування, те, що можна назвати мелодичними контентом з інтонаційними семантичними прототипами.

Так, зокрема, шлях героя циклів музикознавцями розглядається як відображення типово романтичної втрати гармонії зі світом та роздвоєння свідомості людини, що не здатна знайти спокій у самопізнанні, у діалозі з власною уявою, тобто негаразди зовнішнього світу виявляються віддзеркаленням внутрішнього психологічного розладу, i навпаки. 3 іншого боку, можливе тлумачення сюжетики циклу як узагальнення долі людини у їі найбільш широкому розумінні, просто як шлях від народження до смерті, який завжди може бути витлумаченим як трагічний. Але в обох циклах, і у другому також, ідея відходу людини з життя передається зі стоїчним спокоєм, хоча з глибоким 
емоційним реагуванням, як те, чого не можна змінити, отже, з чим треба примиритися.

3 цією естетично-художньою настановою до циклів входить третя, остаточна, іпостась авторського образного комплексу, автор ідеальний або вторинно-взірцевий, або третинний чи третій у діалозі над-адресат у смисловому вимірі художнього твору. Це авторське начало, вірніше спосіб логіко-смислового завершення образу автора, виражається шляхом композиційних повторень та оновлень музичного матеріалу, тобто на основі способів створення цілісної композиції, організації іiї змістової єдності, власне циклічності. I знову тут провідними стають суто музичні прийоми розгортанні тексту, побудови форми, оскільки навіть у виборі та розміщенні віршів, у їх внутрішньому структуруванні проявляється композиторська воля; вони підпорядковані розвитку музично-мовної площини твору та музично-звуковій формі вираження художніх ідей й відбиття образних уявлень.

\section{СПИСОК ЛІТЕРАТУРИ}

1. Богомолов С. Песни Франца Шуберта как высокий жанр: дис. ... канд. искусствоведения. СПб., 2000. 150 с.

2. Вульфиус П. А. Франц Шуберт: Очерки жизни и творчества. М., 1983.

3. Гольдшмидт Г. Франц Шуберт. М.: Музгиз, 1960. 437 с.

4. Демченко Г. О чертах романтизма в фортепианных миниатюрах Шуберта. Шуберт и шубертианство. Харьков, 1994. С. 64-67.

5. Зенкин К. Шуберт и романтизм. О некоторых аспектах свободы выражения в фортепианных пьесах. Шуберт и шубертианство. Харьков, 1994. C. $55-60$.

6. Конен В Шуберт. 2-е изд., доп. М.: Музгиз, 1959. 303 с.

7. Сидорова О. Шуберт Ф. Вокальный цикл «Зимний путь»: композиционные особенности крупной и малых форм. URL: http:// gnesinstudy.ru/wp-content/uploads/2016/12/SidorovaEV1.pdf

8. Хохлов Ю. Песни Шуберта. Черты стиля. М., 1987.

9. Хохлов Ю. Шуберт. Музыка. БЭС / гл. ред. Г. В. Келдыш. М.: Большая Российская энциклопедия, 1998. С. 646-647.

10. Хохлов Ю. Ф. Шуберт. Жизнь и творчество в материалах и документах. M., 1978. $324 \mathrm{c}$.

11. Шапинская Е. «Зимний путь» Шуберта в современной культуре: вечные вопросы бытия и тоска по утраченным ценностям. Культура культуры. 2015. № 1. URL http://cult-cult.ru/schubert-s-die-winterreise-incontemporary-culture-the-eternal-questions-of-bein/ 
12. Youens S. Retracing a Winter's Journey: Schubert's Winterreise. Ithaca and London, 1991. $331 \mathrm{~s}$.

13. Youens S. Schubert; Die schone Mullerin. Cambridge, 1992. $123 \mathrm{~s}$.

\section{REFERENCES}

1. Bogomolov, S. (2000). Songs of Franz Schubert as a high genre. Candidate's thesis. SPb. [in Russian].

2. Wulfius, P. A. (1983). Franz Schubert: Essays on life and creativity. M. [in Russian].

3. Goldschmidt, G. (1960). Franz Schubert. M.: Muzgiz [in Russian].

4. Demchenko, G. (1994). On the traits of romanticism in the piano miniatures of Schubert // Schubert and Schubertianism. Kharkov. P. 64-67 [in Russian].

5. Zenkin, K. (1994).Schubert and Romanticism. On some aspects of freedom of expression in piano pieces // Schubert and Schubertianism. Kharkov. P. 55-60 [in Russian].

6. Conen, W. (1959)/ Schubert. 2 nd ed., Ext. M.: Muzgiz [in Russian].

7. Sidorova, O. Schubert F. The vocal cycle «Winter Path»: compositional features of large and small forms. URL: http://gnesinstudy.ru/wp-content/uploads/2016/12/SidorovaEV1.pdf [in Russian].

8. Khokhlov, Yu. (1987). Songs of Schubert. Features of style. M. [in Russian].

9. Khokhlov, Yu. (1998). Schubert // Music. BES. Ch. Ed. G. V. Keldysh. M.: NI «The Great Russian Encyclopedia. P. 646-647 [in Russian].

10. Khokhlov Yu. (1978). F. Schubert. Life and work in materials and documents. M. [in Russian].

11. Shapinskaya, E. «Winterreise» by Schubert in modern culture: the eternal questions of life and longing for lost values // Culture Culture number 1, 2015. URL: http://cult-cult.ru/schubert-s-die-winterreise-in-contemporary-culturethe-eternal-questions-of-bein /[in Russian].

12. Youens, S. (1991). Retracing a Winter's Journey: Schubert's Winterreise. Ithaca and London [in English].

13. Youens, S. (1992). Schubert; Die schone Mullerin. Cambridge [in English].

Стаття надійцла до редакції 22.03.2017

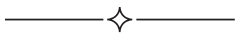

